\title{
Dinoflagellate Bloom of Karenia mikimotoi along the Southeast Arabian Sea, Bordering Western India
}

\author{
R. S. Robin, ${ }^{1}$ Vishnu Vardhan Kanuri, ${ }^{2}$ Pradipta R. Muduli, ${ }^{2}$ Rajani K. Mishra, \\ M. Jaikumar, ${ }^{4}$ P. Karthikeyan, ${ }^{1}$ C. Suresh Kumar, ${ }^{5}$ and C. Saravana Kumar ${ }^{6}$ \\ ${ }^{1}$ Centre of Advanced Study in Marine Biology, Faculty of Marine Sciences, Annamalai University, Parangipettai 608 502, India \\ ${ }^{2}$ Department of Inorganic and Analytical Chemistry, Andhra University, Visakhapatnam 530 013, India \\ ${ }^{3}$ NCAOR, Ministry of Earth Sciences, Government of India, Headland Sada, Goa 403 804, India \\ ${ }^{4}$ Aquaculture Foundation of India, Number 4/40 Kapaleeswarar Nagar, Neelankarai, Chennai 600 115, India \\ ${ }^{5}$ Institute for Ocean Management, Anna University, Chennai 600 025, India \\ ${ }^{6}$ Applied Microbiology, PSG College of Arts and Science, Coimbatore 641 014, India
}

Correspondence should be addressed to R. S. Robin; robin.ocean1@gmail.com

Received 6 February 2013; Accepted 30 April 2013

Academic Editor: Felipe Garcia-Rodriguez

Copyright (C) 2013 R. S. Robin et al. This is an open access article distributed under the Creative Commons Attribution License, which permits unrestricted use, distribution, and reproduction in any medium, provided the original work is properly cited.

A harmful algal bloom (HAB) occurred along the southeast Arabian Sea, bordering Western India, during September to November 2004. This bloom was unique in the region in terms of its large spatial extent, and the trend was weakened towards November. Mass mortality of fish, emanation of noxious odour, and respiratory problems among the children on the coastal stretch were noticed. The phytoplankton species Gymnodiniium, class Dinophyceae bloom accounted for $98 \%$ of the standing crop. The bloom Karenia mikimotoi showed a maximum density of $19.37 \times 10^{4}$ cells $\mathrm{L}^{-1}$ and $18.94 \times 10^{4}$ cells L $^{-1}$ at nearshore and offshore, respectively. The remotely sensed chlorophyll $a(\mathrm{Chl} a)$ data from seaWiFS, sea surface temperature (SST) from advanced very high resolution radiometer (AVHRR), rainfall from tropical rainfall measuring Mission (TRMM), and Sea winds from QuickSCAT reflected the bloom due to Karenia mikimotoi, suggesting the advection process at the coastal waters. The release of toxins specifically the neurotoxic shellfish poisoning (NSP) and azaspiracid shellfish poisoning (AZP) from the bloom was assessed by chemical and mouse bioassay of the extract from mussel Perna indica, showing negative results. These indicate that asphyxiation and abnormal mucus secreted by the K. mikimotoi led to clogging of gills that accentuated the mass fish kills.

\section{Introduction}

There is a concern for HABs due to their deleterious effects on marine resources, such as death of marine mammals, birds, and sea turtles. It causes food web disruption and adversely affects local and regional economies [1]. Several international organizations have focused on HABs, the factors responsible for the events, potential toxicity, and impact. Hydrographic parameters such as current, temperature, and salinity fronts have contributed to the formation of HABs [2]. Additionally, shallow shelves with seasonal changes in hydrographic feature influence the initiation, growth, and transport of blooms, [3] and climatic conditions also affect the occurrence of these features [4]. The role of nutrients in the evolution of HABs has finally been documented [5-7]. Wind patterns, moreover, contribute to periodic coastal upwelling and downwelling potentially influencing onshore and offshore movements of bloom. Further, current intrusion [8-10], thermal fronts concentrate and transport bloom populations [11-15], and their role in toxic bloom formation have been investigated using satellite images [16]. To observe widely and quantify the HABs are much difficult for the entire coast due to its spread in spatiotemporal variation during September to November 2004 . Hence, we collected and analyzed remotely sensed data. The validation of sea truth data of K. mikimotoi dinoflagellate bloom with the satellite image of $\mathrm{Chl} a$ measures the magnitude in the range of the southwest coast at Arabian Sea with respect to environmental and metrological conditions. This would help us for future early warning and the environmental condition which causes the mass mortalities of fish in turn the 
human population and socioeconomic development. Earlier research has been conducted through satellite measurement of various parameters validating the $\mathrm{Chl} a$ due to light trap phototaxis, nutrient availability by rainfall, or cell transport by wind strength and direction which prolonged large bloom in Scottish waters [17]. Therefore, with in situ limitation, we analyzed the satellite data for the potential of bloom and $\mathrm{Chl}$ a SST, rainfall, and sea winds along the coast.

Cell fragments resulting from the disintegration are carried by ocean spray produced via the bubble-bursting process typically resulting from whitecap generation that occurs at high wind speeds and can affect either upper and/or lower airway symptoms [18]. Further, HABs produce potent toxins that can be transferred through the food web, where they induce and kill the higher forms such as zooplankton, shellfish, finfish, birds, marine mammals, and even humans [19]. An overview of neurotoxic shellfish poisoning (NSP) and azaspiracid shellfish poisoning (AZP) and its analytical methods has been documented [20]. Shellfish poisoning from the toxins secreted by certain dinoflagellates also has been recorded [21]. In many instances, the toxin is stored in the digestive gland or siphon of the shellfish [22]. Besides toxins, the production of mucous by some algal blooms may influence fish and invertebrates [23].

For the first time, a dinoflagellate bloom of K. mikimotoi was observed in the southeast Arabian Sea, off the coast of Thiruvananthapuram, India, during the third week of September 2004 and continued for three months. The bloom was accompanied by massive fish kills and respiratory problems in the nearby coastal population. In this study, the nature and cause of bloom formation in relation to climatic condition, hydrographic features, and remotely sensed data have been examined; chemical and mouse bioassay tests for neurotoxic shellfish poisoning (NSP) and azaspiracid shellfish poisoning (AZP), in the mussel Perna indica, were also undertaken.

\section{Materials and Methods}

2.1. Study Area. The algal bloom occurred over three months on the Arabian Sea, near the Thiruvananthapuram coast between latitude $8^{\circ} 22^{\prime} \mathrm{N}$ and $8^{\circ} 34^{\prime} \mathrm{N}$ and longitudes $76^{\circ} 48^{\prime}$ $\mathrm{E}$ and $76^{\circ} 59^{\prime} \mathrm{E}$. In the study area, six transects were selected at $4 \mathrm{~km}$ intervals at Puthenthura, Pallithura, Veli, Shanghumugham, Muttathara, and Panathura, respectively, stretching from north to south along the coast (Figure 1). Two stations, on each of these transects, were considered as one nearshore and offshore within $10 \mathrm{~km}$ from the coast.

2.2. Sampling Strategy. Representative samples were collected from both stations, using a $10 \mathrm{~L}$ Niskin sampler. For the collection of algae, $1 \mathrm{~L}$ samples each was passed through a $20 \mu \mathrm{m}$ net; samples were fixed with Lugol's iodine and $4 \%$ formalin. Shellfish samples for toxin analysis and toxicity studies were collected from the area, frozen, brought to the laboratory, and stored in a deep freezer at $-80^{\circ} \mathrm{C}$ for further analysis. Besides the shellfish, dead finfishes were also collected to trace the cause of death.

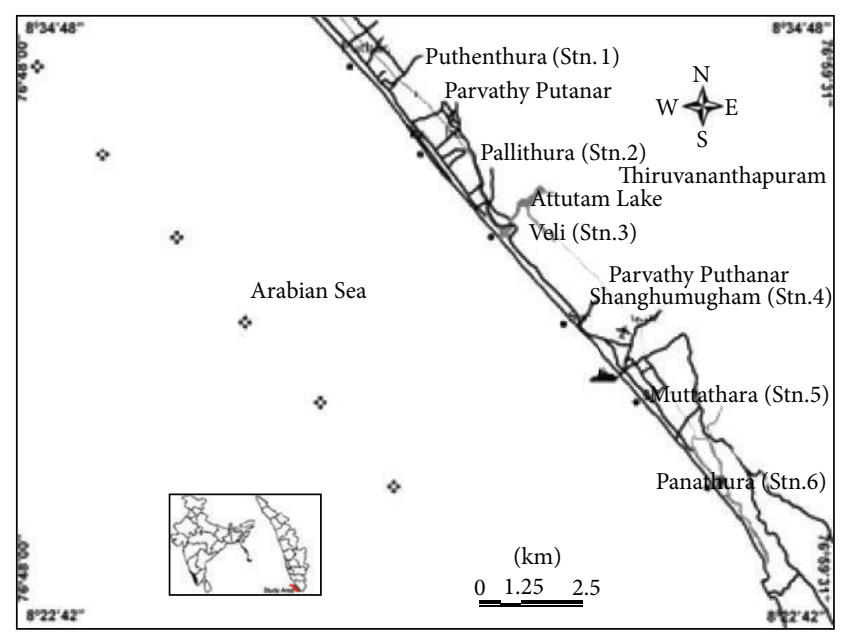

- Nearshore locations

* Offshore locations

, Roads

* Airport

FIGURE 1: Map showing sampling location of study area.

2.3. Physicochemical Parameters. Meteorological data (rainfall) collected from (Indian Meteorological Department) for a period of study recorded at Thiruvananthapuram station was examined, and the average values are presented. In situ temperature was recorded using a thermometer $\left(1-51^{\circ} \mathrm{C}\right.$ range within $\pm 0.1^{\circ} \mathrm{C}$; Brannan, UK). Salinity was measured by argentometric titration, and nutrients were estimated following [24]. Current speed was measured by deploying self-recording current meter for $15 \mathrm{~min}$ at 6 selected stations. Wind speed data for premonsoon was collected from the selfrecording weather station (R.M. Young, USA; Model 05106) installed on the west shore of Thiruvananthapuram. Oxygen was measured using Winkler's method [25]. Samples for $\mathrm{pH}$ were collected in $100 \mathrm{~mL}$ glass bottles, poisoned with $100 \mu \mathrm{L}$ of saturated mercuric chloride, and sealed airtight. The $\mathrm{pH}$ was measured using a ROSS combination glass electrode (ORION 8102U) and pH meter (ORION 555A). Analytical precision for $\mathrm{pH}$ of samples was \pm 0.02 . All carboys, filtering devices, glassware, and tubings were acid-washed $(10 \% \mathrm{HCl})$ and rinsed thrice with deionized water prior to use. Bottles were rinsed twice with their own volume of sample, capped, and stored in the dark at $4^{\circ} \mathrm{C}$ until analysis. Analyses for nutrients, $\mathrm{NO}_{2}{ }^{-}, \mathrm{NO}_{3}{ }^{-}, \mathrm{PO}_{4}{ }^{3-}$, and $\mathrm{NH}_{4}{ }^{+}$were done within 6 hours of collection, following filtration through $0.45 \mu$ filters into acid-rinsed containers. Concentrations were determined as suggested by standard methods [24]. Iron was analyzed by 1,10-phenanthroline method and sulphide using the methylene blue method [26].

2.4. Pigment Extraction (Chl a). For pigment extraction, $1 \mathrm{~L}$ water samples were filtered through Whatman GF/F glass fiber filters, which were then immersed in $10 \mathrm{~mL} 90 \%$ acetone and allowed to extract in darkness at $20^{\circ} \mathrm{C}$ for approximately 24 hours. After extraction, the samples were vortexed. The 
samples were then centrifuged, and absorbance of the supernatant was measured using a Perkin Elmer spectrophotometer [27].

2.5. Algal Identification. Algal abundance and species composition, especially for the toxic and harmful microalgae, were assessed $[28,29]$ by quantifying taxa in $1 \mathrm{~mL}$ aliquot subsamples placed in Sedgewick-Rafter counting chambers. Species identification was established using keys of [30, 31].

2.6. Biotoxin Analysis. For the mouse bioassay [32], to $100 \mathrm{~mL}$ of 0.1 molar $\mathrm{HCl}$ was added 100 gm homogenized sample and gently boiled for 5 minutes. After cooling, the $\mathrm{pH}$ was adjusted between 2.0 and 4.0 and diluted to $200 \mathrm{~mL}$ with deionised water. This supernatant was used as the test solution. One $\mathrm{mL}$ each of the solutions was intraperitoneally inoculated in three healthy test mice weighing from 19 to $21 \mathrm{~g}$. Adverse reactions of the mice were recorded for a period of 20 minutes.

2.7. Remote Sensing Data Analysis. [In order to estimate the Sea-viewing Wide Field-of-view Sensor (SeaWiFS) Chl $a$ derived from the Giovanni, an acronym for the GES-DISC (Goddard Earth Sciences Data and Information Services Center) NASA using $9 \mathrm{~km} \times 9 \mathrm{~km}$ resolution.] Monthly sea surface temperature (SST) derived from the five-channel advanced very high resolution radiometer (AVHRR) by NOAA's National Environmental Satellite, Data, and Information Service, Version 5.0, with spatial resolution $4 \mathrm{~km} \times$ $4 \mathrm{~km}$ was derived to correlate the Chl $a$ distribution with respect to HABs. The sea wind's data for seeing ocean wind vector from sea winds on QuickSCAT level 3 daily gridded ocean wind vectors with spatial resolution $25 \mathrm{~km} \times 25 \mathrm{~km}$ during the afternoon for observing the bloom spreading in the coast. Here [the daily surface currents considered the day selected randomly from each week of the month and magnitude accumulated considering from month of September to November to observe the influence patterns for the blooming along the coast.] The rainfall was measured through the tropical rainfall measuring mission (TRMM) for monthly average rainfall data with spatial resolution $25 \mathrm{~km} \times 25 \mathrm{~km}$ using 3B43, Version 6.

\section{Results}

3.1. Hydrographic Conditions. Spatial distributions of various physicochemical parameters for the period of study were well depicted in (Figures 2(a)-2(i)). The temperature of the water varied from $28.22^{\circ} \mathrm{C}$ (nearshore) to $28.52^{\circ} \mathrm{C}$ (offshore) and salinity of 33.9 from nearshore to 35.7 at offshore. Dissolved oxygen levels were as low as $0.2 \mathrm{mg} \mathrm{L}^{-1}$ in nearshore and increased to $3.6 \mathrm{mg} \mathrm{L}^{-1}$ in offshore. The $\mathrm{pH}$ varied from 6.5 nearshore to 8.0 offshore. Levels of $\mathrm{PO}_{4}{ }^{3-}$ concentrations were highest of $11.0 \mu \mathrm{mol} \mathrm{L}{ }^{-1}$ at nearshore to $5.0 \mu \mathrm{mol} \mathrm{L}^{-1}$ at offshore; similarly, high $\mathrm{NH}_{4}{ }^{+}$was measured from nearshore $5.5 \mu \mathrm{mol} \mathrm{L}^{-1}$ to $4.2 \mu \mathrm{mol} \mathrm{L}-1$ at offshore. On the other hand, $\mathrm{NO}_{2}{ }^{-}$and $\mathrm{NO}_{3}{ }^{-}$concentrations were low, $\mathrm{NO}_{2}{ }^{-}$ranging from $0.002 \mu \mathrm{mol} \mathrm{L}^{-1}$ (nearshore) to $0.038 \mu \mathrm{mol} \mathrm{L}^{-1}$ (offshore) and $\mathrm{NO}_{3}{ }^{-}$was in the range of $0.20 \mu \mathrm{mol} \mathrm{L}{ }^{-1}$ (nearshore) to
$1.40 \mu \mathrm{mol} \mathrm{L}^{-1}$ (offshore). However, the concentrations of iron were high in the range of $48.70 \mu \mathrm{mol} \mathrm{L}^{-1}$ to $56.22 \mu \mathrm{mol} \mathrm{L}{ }^{-1}$, whereas the $\mathrm{H}_{2} \mathrm{~S}$ concentration was reached up to $1.6 \mathrm{mg} \mathrm{L}^{-1}$.

3.2. Wind and Water Current. During the period of bloom, predominant winds were southwest and westerly blowing towards the coast from ocean side. The winds from the southwest (SW) direction measure 52\% and south-southwest (SSW) $22 \%$ of the total time, speed, and frequencies in the range of 0-2 $\mathrm{m} \mathrm{sec}^{-1}(0.8 \%), 3-5 \mathrm{~m} \mathrm{sec}^{-1}(1.2 \%), 6-15 \mathrm{~m} \mathrm{sec}^{-1}$ (27\%), 16-20 $\mathrm{m} \mathrm{sec}^{-1}$ (65.5\%), and 21-25 $\mathrm{m} \mathrm{sec}^{-1}$ (5\%). Mean monthly wind speed varied from a minimum $5.2 \mathrm{~m} \mathrm{sec}^{-1}$ (November) to a maximum of $26 \mathrm{~m} \mathrm{sec}^{-1}$ (August). It is noteworthy that the average wind speed during monsoon months (May to August) is twice higher $\left(13.39 \mathrm{~m} \mathrm{sec}^{-1}\right)$ than September and November $\left(6.65 \mathrm{~m} \mathrm{sec}^{-1}\right)$ as shown in Table 1; Figure 3. In the region, the weather often to be proved unpredictable, particularly during the monsoon gusty winds accompanied by heavy rain bringing about a sudden change.

[The wind speed shows appreciably high $\left(>20 \mathrm{~m} \mathrm{sec}^{-1}\right)$ and the current directions follows variable, with winds, tide and local circulation.] Current strength varied from 0.12 to $0.64 \mathrm{~m} \mathrm{sec}^{-1}$. Strong currents $\left(>0.70 \mathrm{~m} \mathrm{sec}^{-1}\right)$ were encountered in September and October at offshore from SW, which is mainly due to the wind driven. A counter circulation prevailed in the southern part during November may be due to the combined effect of wind, tide, and topography. In the southern coast, water movements showed mainly southeast. At nearshore, currents varied between 0.12 and $0.35 \mathrm{~m} \mathrm{sec}^{-1}$. Currents predominated in the speed of 0.21 and $0.26 \mathrm{~m} \mathrm{sec}^{-1}$ and were bidirectional (WSW and SSW). At offshore, current speeds varied between 0.29 and $0.76 \mathrm{~m} \mathrm{sec}^{-1}$ and did not exhibit any relationship with the tide, being highly scattered in different directions.

3.3. Bloom Assemblage. A total of 18 taxa of phytoplankton were identified in the bloom period out of which 14 were diatoms and four were dinoflagellates. Among the diatoms, Chaetoceros lorenzianus, Thalassionema nitzschioides, Coscinodiscus eccentricus, and Skeletonema costatum were observed. Whereas Karenia mikimotoi, Ceratium macroceros, Peridinium depressum, and Prorocentrum micans were identified under dinoflagellates. Among the population, K. mikimotoi contributed up to $98 \%$, which belongs to order Gymnodinials, family Gymnodiniaceae (Figure 4). Earlier, it was known as Gymnodinium and recently has been changed to the genus Karenia [33].

3.4. Mucous Causing Fish Kills. As the bloom declined, a massive mortality of fish occurred. The variety of dead fish was identified to belong to the families Scombridae (Rastrelliger kanagurta), Clupeidae (Sardinella longiceps), Ariidae (Arius arius), Siganidae (Siganus javus), Psettodidae (Psettodes erumei), Balistidae (Monacanthus hispidus), Tetraodontidae (Diodon hystrix), and Anguillidae (Anguilla sp.). The bloominduced area was found to be covered by slimy mucous, partly washed ashore. Microscopic examinations of the dead fishes showed that their gills were coated with mucous. 


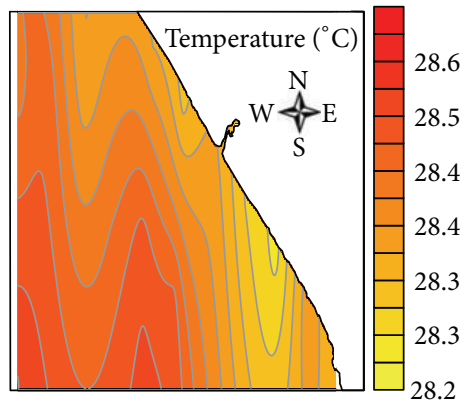

(a)

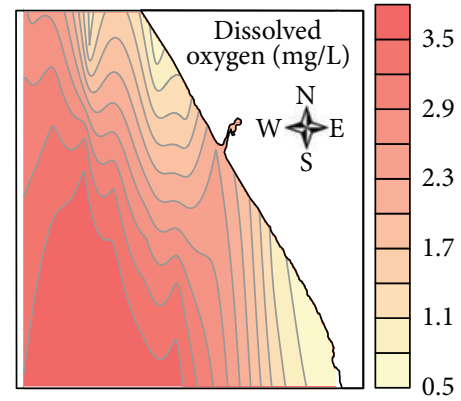

(d)

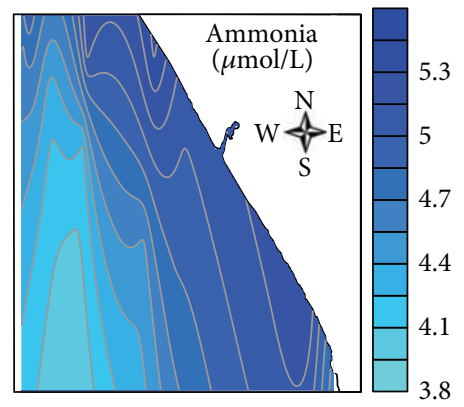

(g)

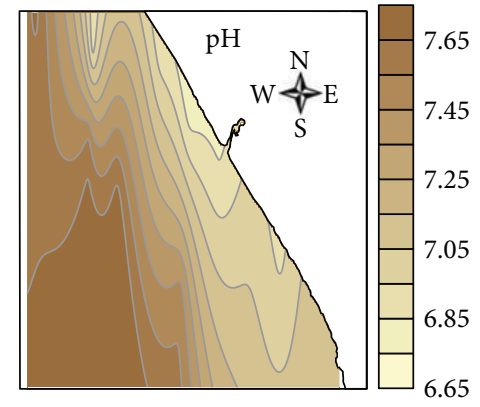

(b)

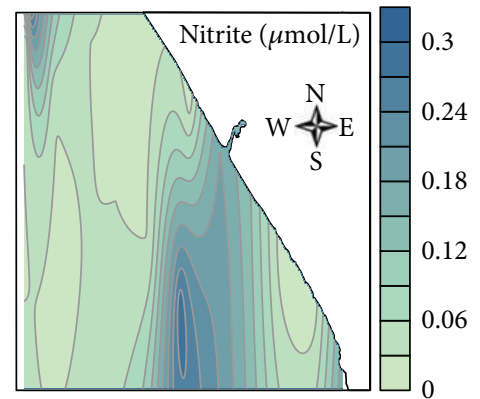

(e)

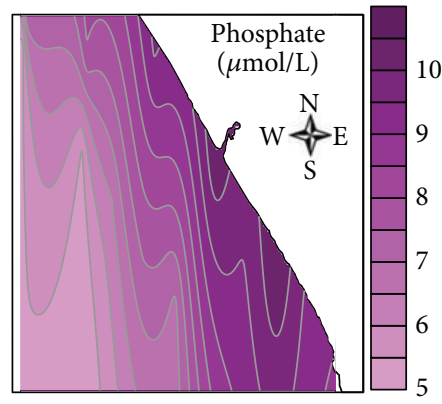

(h)

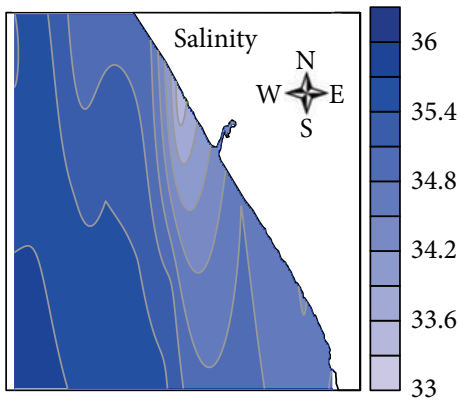

(c)

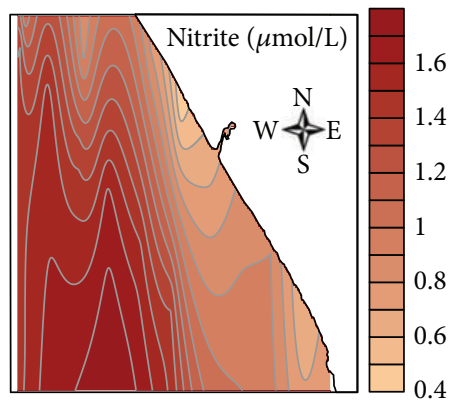

(f)

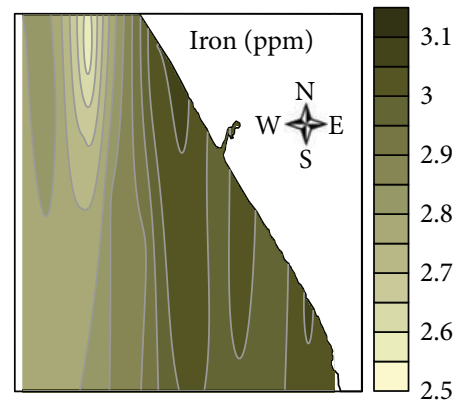

(i)

FIGURE 2: Average spatial variation of (a) temperature $\left({ }^{\circ} \mathrm{C}\right)$, (b) salinity, (c) dissolved oxygen $\left(\mathrm{mgL}^{-1}\right),(\mathrm{d}) \mathrm{pH},(\mathrm{e}) \mathrm{phosphate-P}\left(\mu \mathrm{mol} \mathrm{L}{ }^{-1}\right)$, (f) ammonia-N $\left(\mu \mathrm{mol} \mathrm{L}^{-1}\right)$, (g) nitrite- $\mathrm{N}\left(\mu \mathrm{mol} \mathrm{L}^{-1}\right)$, (h) nitrate- $\mathrm{N}\left(\mu \mathrm{mol} \mathrm{L} \mathrm{L}^{-1}\right)$, (i) and iron $\left(\mu \mathrm{mol} \mathrm{L}^{-1}\right)$ at study site during September to November 2004.

3.5. Biotoxicity. Algal blooms can be toxic or nontoxic depending on the species. Since K. mikimotoi was identified and considered toxic, chemical and bioassays for the toxin were carried out for the extracts of mussel Perna indica. However, the fluorescence spectra did not show the peak, corresponding to the neurotoxic shellfish poisoning and azaspiracid shellfish poisoning (AZP). Hence, the toxin even if present was below the detection limit of $10^{-9} \mathrm{M}$. The same was reflected when the extract was injected intraperitoneally in healthy mice, which did not give any adverse reaction, indicating that the concentration of the toxin, even if present in the mussel, was below $10 \mu \mathrm{g} \mathrm{Kg}^{-1}$, the $\mathrm{LD}_{50}$ of mice.

3.6. Remote Sensing and Bloom Distribution by Satellite Parameter Analysis. The study site shows dynamic changes in both spatial and temporal chlorophyll concentration from northwest to southwest by satellite remote sensing (Figure 5(a)). The results clearly indicated the distribution of
Chl $a$ from the northwest region to the southwest region followed by generalized distribution pattern, [seeing the satellite image it was concomitant with the wind vector distribution (Figure 3).] Concerned with spatial distribution, the variation was maximum at the northwest region and gradually scattered to southwest and further led to the east coast of Tamil Nadu within $200 \mathrm{~km}$ stretch. The reason of a high bloom concentration is due to the river Karamana which originates from the southern tips of Western Ghats and spreads about $68 \mathrm{~km}$ towards the westward region merging into the Arabian Sea at Thiruvananthapuram coast. The river discharges largely during the monsoon with abundant nutrient load to the coast. [It is evident from the rain fall which was derived from the TRMM data, observed to be moderate rainfall between 350 to $500 \mathrm{~mm}$ triggers bloom with the minimum level of nutrient required by K. mikimotoi was found during September.] However, rainfall clears the bloom, scatters the bloom from September to October, and further lessns towards November. 
TABLE 1: Atmospheric temperature, wind speed, direction, and rainfall at Thiruvananthapuram, Kerala.

\begin{tabular}{|c|c|c|c|c|c|c|c|c|}
\hline \multirow{2}{*}{$\begin{array}{l}\text { Year } \\
2004\end{array}$} & \multicolumn{3}{|c|}{ Atmos. temp $\left({ }^{\circ} \mathrm{C}\right)$} & \multicolumn{3}{|c|}{ Wind speed $\left(\mathrm{m} \mathrm{sec}^{-1}\right)$} & \multirow{2}{*}{ Wind direction } & \multirow{2}{*}{$\begin{array}{c}\text { Rainfall (mm) } \\
\text { Mean }\end{array}$} \\
\hline & Min. & Max. & Mean & Min. & Max. & Mean & & \\
\hline May & 28.80 & 32.60 & 29.88 & 5.09 & 15.88 & 10.51 & SW \& SSW & 252.63 \\
\hline June & 26.40 & 31.10 & 29.51 & 6.01 & 17.02 & 11.57 & SW \& SSW & 462.53 \\
\hline July & 26.50 & 31.00 & 28.64 & 7.03 & 22.89 & 14.12 & SW \& SSW & 412.29 \\
\hline August & 26.30 & 30.50 & 28.67 & 9.24 & 26.41 & 17.36 & SW \& SSW & 494.71 \\
\hline September & 24.30 & 30.50 & 28.80 & 4.36 & 14.52 & 9.64 & SW \& SSW & 325.86 \\
\hline October & 24.90 & 30.50 & 27.06 & 2.02 & 11.12 & 6.23 & SSW \& WNW & 336.74 \\
\hline November & 22.30 & 27.40 & 24.53 & 1.02 & 7.01 & 5.20 & WNW \& WNW & 98.36 \\
\hline December & 21.10 & 24.40 & 22.67 & 1.37 & 8.01 & 5.52 & WNW \& NW & 35.92 \\
\hline
\end{tabular}

These show the greater temporal variation of $\mathrm{Chl} a$ distribution along the coast, which is 15 folds less than of peak (September) and spreads about $150 \mathrm{~km}$ from nearshore to west wide region. [The SST showed variation within $2^{\circ} \mathrm{C}$ (i.e., $26-28^{\circ} \mathrm{C}$ ) during September indicates the bloom intensification, with optimum temperature and distribution of $\mathrm{Chl} a$ subsequently decreased during October and November.] The temperature is directly influenced by the magnitude of the rainfall in October and November as seen from the SST and TRMM (Figures 5(b), and 5(c)) distributions in the coast.

The wind speed and direction observed from QuickSCAT during peak of monsoon (September) was 4 to $18 \mathrm{~m} \mathrm{~s}^{-1}$, and during the postmonsoon in October and November, it varied 1-9 \& 2-10 $\mathrm{m} \mathrm{s}^{-1}$, respectively. The results similarly matched with the metrological data that have been collected at the site during October 2004 (Table 1), and wind direction was from south and southwest to the southeast region during the monsoon (September-October), and it turned back from southeast to southwest during postmonsoon (November) as shown in Figure 3. Almost the unidirectional and high magnitude wind revealed the bloom intensification in September from south to southwest coast and subsequently transparent towards October than in November as shown in our satellite image. Again, the wind reversal from the end of October and bidirectional in November with low magnitude were intensified and scattered southern region from coast to offshore.

\section{Discussion}

Earlier algal blooms reported in the Arabian Sea have occurred further north (latitude $9^{\circ}$ ) of Kochi, Mangalore, and Goa usually in the premonsoon, that is, March-May [34]. This is the first time that an event of K. mikimotoi has occurred in the southwest coast of India. Unusually, the bloom period was marked by high intensity, short duration rainfall with intermittent high daytime temperatures $\left(+3^{\circ} \mathrm{C}\right.$, more than normal). The upwelling zone and adjacent thermally stratified waters off the southwest coast could be an ideal site for bloom formation. It has been discussed in the backdrop of winds and oceanic currents $[34,35]$ and surmised that the equator ward and offshore components were favorable to upwelling, whereas the pole ward and onshore components act against upwelling. In the present study, it was seen that the winds were mainly onshore SW and
SSW and as such were unfavorable in upwelling, in agreement with temperature and salinity patterns; low temperature and low salinity (Figures 2(a), and 2(c)).

During the study period, $62 \%$ of wind came from the northwest and southwest quadrants and 22\% from the southwest alone. This wind direction provided ideal conditions for transporting large biomass of this bloom into the inner parts of the southwest coast, where it had the greatest impact. In support wind speed and direction (Figure 3 and Table 1), which have been observed through QuickSCAT initially with very high winds, caused the currents favorable to south and southwest region to scatter further southwest as shown in Figure 3. Afterwards during the end of October and in November both clockwise and anticlockwise wind circulations prevailed the bloom at the southern region and spread to the southwest coast as seen from the Chl $a$ distribution, which might be due to the combined effect of wind, current, and bathymetry. It shows the cyclonic eddies formed and the bloom sustained within the wind pattern at the west coast between September and November. In summary, the wind speeds were generally low during September, providing low levels of turbulence and fairly calm conditions, which are ideal for the development of dinoflagellate blooms. The wind direction was mostly onshore, which led to the accumulation of high numbers of cells in coastal embayment and at the shores of the southwestern seaboard; also, expected climatic conditions could have triggered the bursting of K. mikimotoi cysts buried in the sea bottom leading to rapid multiplication. The bloom of $K$. mikimotoi was elevated nearshore, governed by water currents, wind direction, and its strength [36], and formed advection process as seen in Scottish coastal water [17].

The present study analyzed the causes of algal blooms explosive growth that was traced due to sudden increase in supply of nutrients. The high concentrations of nutrients $\left(5.5 \mu \mathrm{mol} \mathrm{L}^{-1} \mathrm{NH}_{3}, 10.5 \mu \mathrm{mol} \mathrm{L}^{-1} \mathrm{PO}_{4}{ }^{3-}\right.$ and $\left.2.7 \mathrm{mg} \mathrm{L}^{-1} \mathrm{Fe}\right)$ can be attributed to heavy runoff from Veli Lake, Karamana river, and Parvathy Puthanar, which receives large quantities of effluents from industrial plots, [city sewage system and domestic sources enter the coastal belts of Thiruvananthapuram] (Figures 2(g)-2(i)). Nutrient data indicated that the concentration of Ammonia was rather high. Many HAB species display a preference for ammonia over other nitrogenous nutrients, revealed elsewhere [37-39]; further 

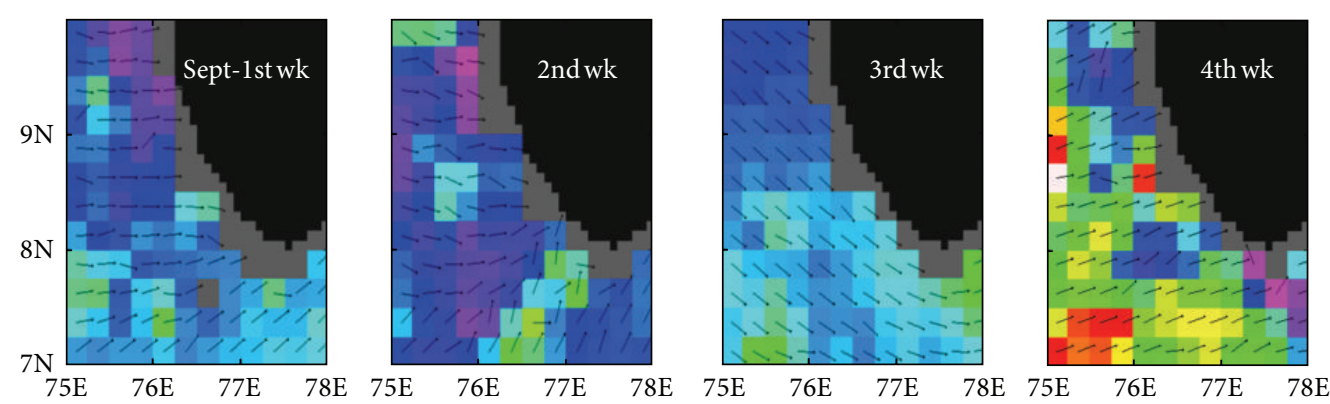

(a)
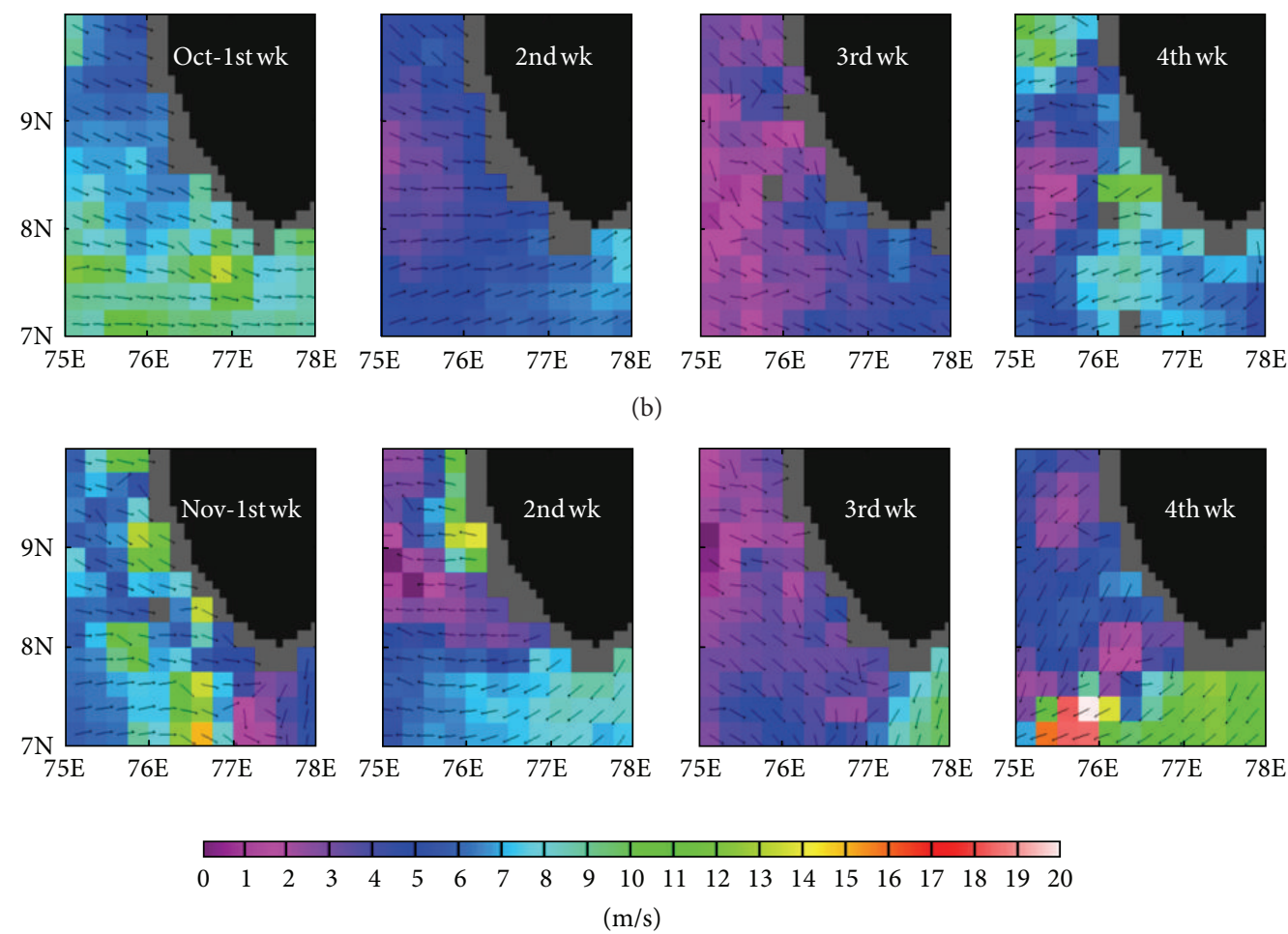

(c)

FIGURE 3: Weekly average sea winds distribution images from QuickSCAT during September to November 2004.

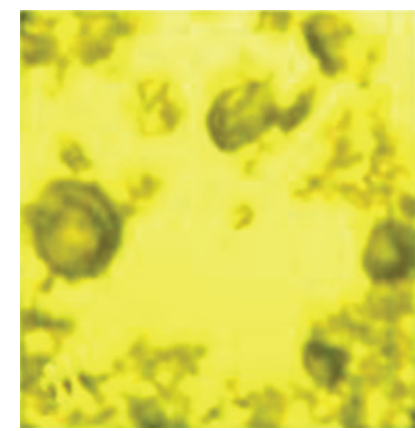

(a)

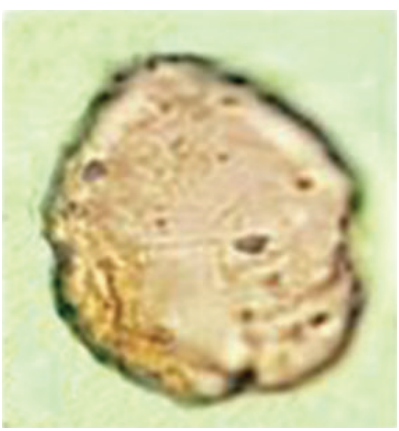

(b)

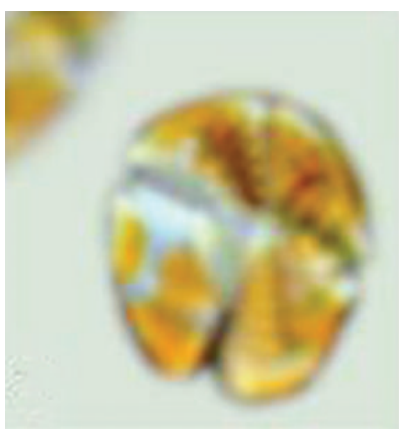

(c)

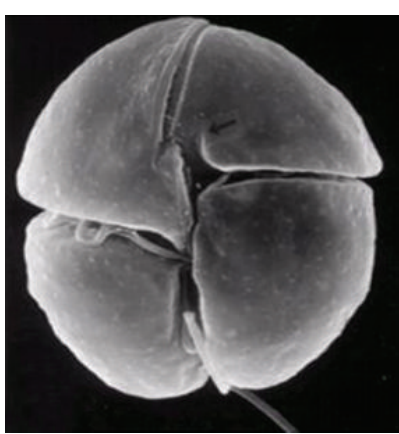

(d)

FIgURE 4: Photomicrograph of Karenia mikimotoi, showing 1 (a) Soup of K. mikimotoi. (b)-(d) Ventral view, length: 16-34 $\mu$ m, width: 14$36 \mu \mathrm{m}$. 


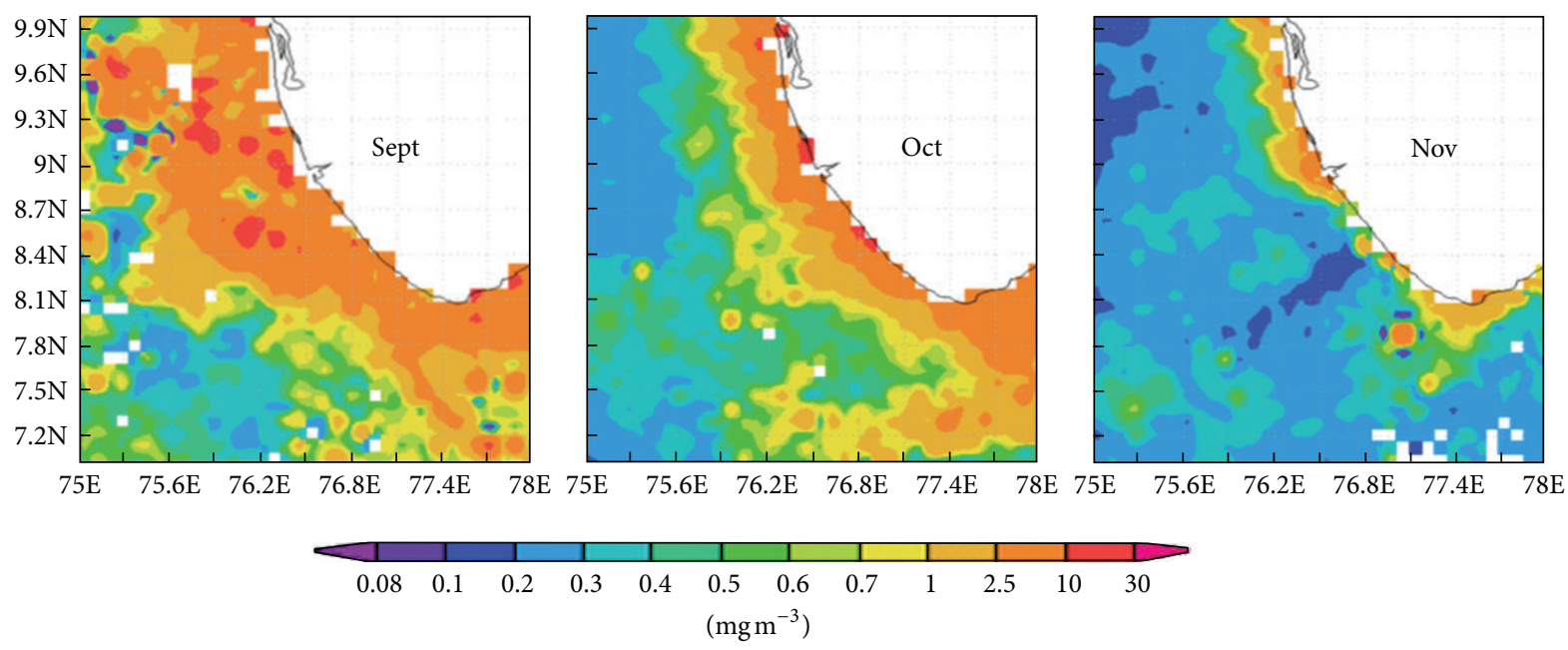

(a)

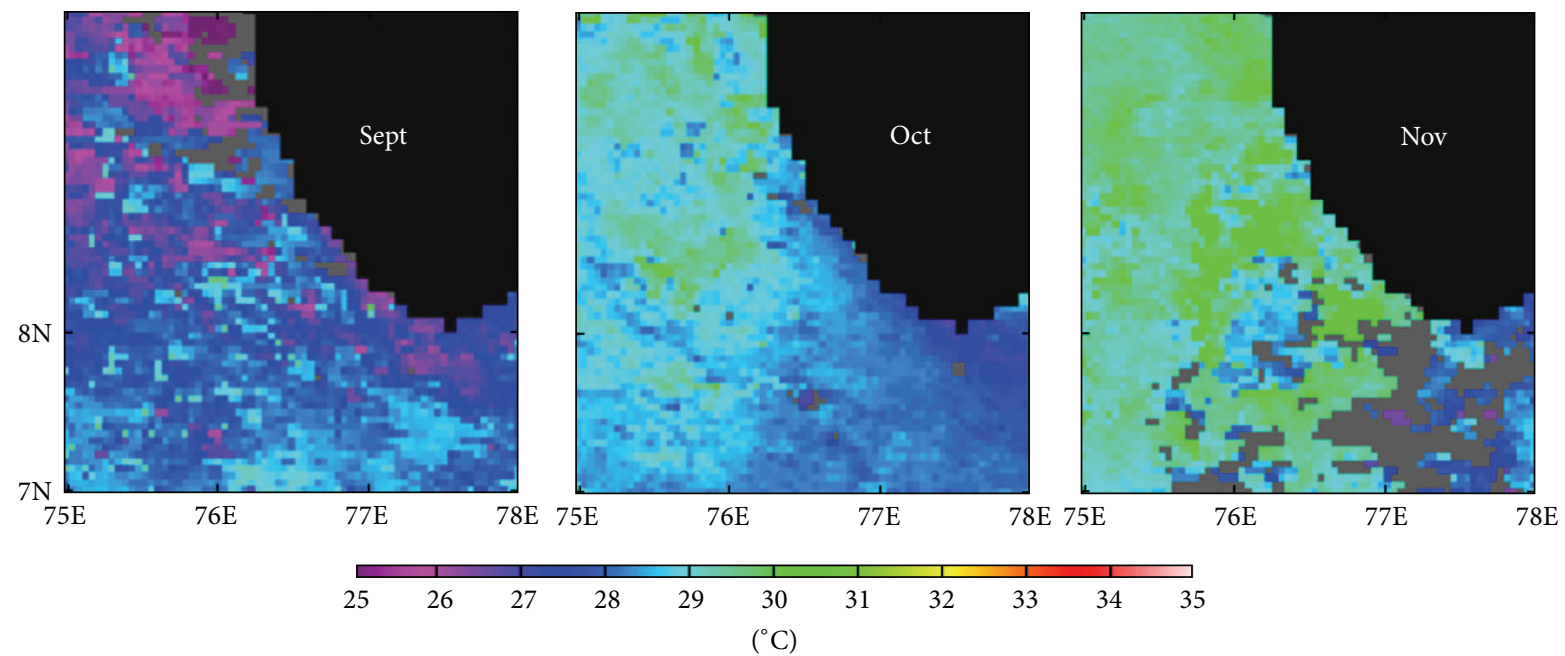

(b)
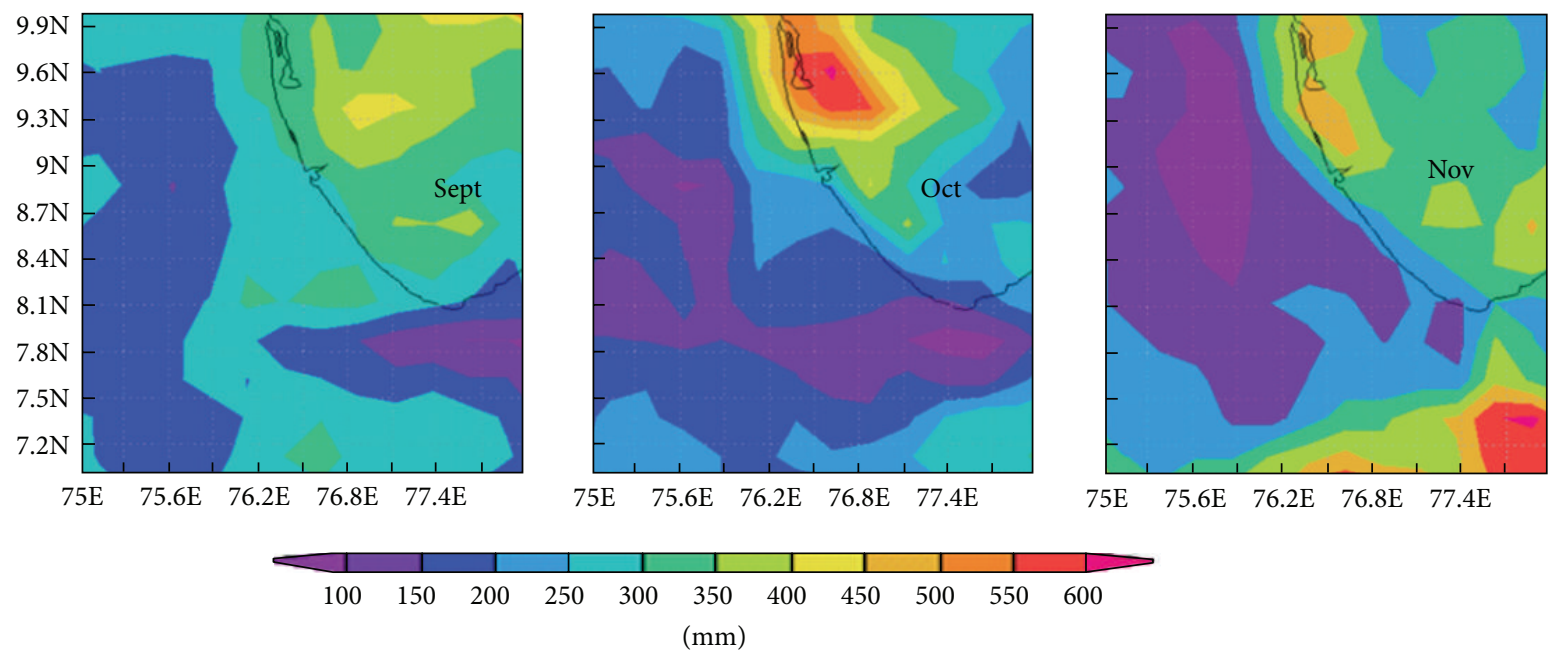

(c)

FIGURE 5: Monthly average satellite (a) Chl $a$ images from SeaWiFS, (b) sea surface temperature (SST) from AVHRR, (c) rainfall from TRMM during September to November 2004. 
concentrations of phosphate $\left(11 \mu \mathrm{mol} \mathrm{L}^{-1}\right)$ and iron (2.71$3.13 \mathrm{mg} \mathrm{L}^{-1}$ ) were high. This abnormal supply of the nutrients [7] along with the presence of iron, acting as a catalyst, resulted in the proliferation of algae. In addition, the unusual climatic factors of high intensity, short duration rainfall with intermittent high daytime temperatures prevalent at the time resulted in stratification and the consequent bloom.

Usually red tide dinoflagellate blooms are quantitatively high and qualitatively poor, resulting in low diversity [followed in the present case represents the climax phytoplankton community structure] where the time frame is controlled by nutrient enrichment due to change in $\mathrm{N}, \mathrm{P}$ ratios, which are in well agreement with the earlier report of [40]. Maximum chlorophyll values compared favorably with those reported in high density blooms elsewhere and observed by K. mikimotoi above $100 \mathrm{mg} \mathrm{m}^{-3}$ in the English channel [41]. A red tide was described in western Scotland, where chlorophyll levels reached $2200 \mathrm{mg} \mathrm{m}^{-3}$ [42] resulting in spectacular water discoloration. Visible discoloration becomes noticed when chlorophyll concentrations exceed approximately $10 \mathrm{mg} \mathrm{m}^{-3}$ [42], [followed our result of $23 \mathrm{mg} \mathrm{m}^{-3}$ might be the case.] Pigments could absorb and algal cells scattered a substantial fraction of submarine light.

Many fish killing phytoplankton are known worldwide. The actual toxicity of these species is not fully understood. The fluorescence studies along with the mouse bioassay indicated that the present bloom of $\mathrm{K}$. mikimotoi did not release any significant toxins, particularly. However, mass fish mortality has been traced to be due to a combination of decreased levels of oxygen saturation, or anoxic conditions that result from the decomposition of the algae. At the later stages of the bloom, respiration by the algae themselves as well as bacterial respiration associated with the breakdown of the bloom consumes oxygen; elevated concentrations of ammonia [43] and releasing of sulphide may have stressed the fish, affecting their metabolism and immunity responses.Fish kills along the coast of Thiruvananthapuram are often marked with an odour resembling rotten eggs; characteristic of $\mathrm{H}_{2} \mathrm{~S}$ is highly toxic to most organisms and perceptible even at concentration of $0.002 \mathrm{mg} \mathrm{L}^{-1}$, which was much lesser than in the present concentration of $1.6 \mathrm{mg} \mathrm{L}^{-1}$. [Usually production of dimethyl sulphide (DMS), principal gaseous form of sulphur in coastal waters formed during phytoplankton bloom simulations for the growth and senescence phases of biomass [44].] This gas production during the senescence phase is several times higher than during the growth phase. Thus, DMS production by the senescence process of K. mikimotoi could be one of the major reasons for elevated levels of $\mathrm{H}_{2} \mathrm{~S}$ putrid smell, which results from the mass fish kills, nausea, and respiratory problem to the public. Furthermore, it has been reported that gill tissue dysfunction by suffocation and decrease in oxygen partial pressure of arterial blood due to excessive covering of gills by mucus would have led to asphyxiation and death of fish. Hishida et al. [45] also made the similar observation on yellowtail exposed to red tide dinoflagellate. Although mucous production is a general phytoplankton trait, dinoflagellates secrete exceptionally large amounts of mucous during blooms that can be viscous, slimy, and fibrous [46-49]. Gunther et al. [50] observed that during a Karenia brevis bloom, the water column appeared slimy and gelatinous, as if covered by an oily scum. The underlying mechanisms by which K. mikimotoi exert ichthyotic effects are still controversial, as for another point of view on toxic substance. It was found that K. mikimotoi generate reactive oxygen species (ROS), [Yamasaki et al., [51] such as superoxide, hydrogen peroxide, and the hydroxyl radical, under the normal conditions [52]] which have potentially deleterious effects on the biological system due to damage of proteins, lipids, and nucleic acids [53]. The fundamental mechanism by which superoxide is generated by red tide dinoflagellates is thought to be the involvement of $\mathrm{NAD}(\mathrm{P}) \mathrm{H}$ oxidase [54] showing that scavenging activity against superoxide generated enzymatically by a hypoxanthine- (HPX-) xanthine oxidase (XOD) system is thought to be one of the self-defense mechanisms against self-production of ROS. For marine organisms to survive in the sea, it is expected that they possess antioxidants effective in protecting themselves from oxidative stress.

In west coast of India, HABs have caused tremendous environmental and socioeconomic losses [34] during summer. Similarly, during the monsoon period, it has been seen at the same coast by Karunasagar et al. [55] and at Tamilnadu coast by Bhat and Matondkar [56]. Hence, the HAB monitored by satellite remote sensing is an expanding application of remote sensing retrieved $\mathrm{Chl} a$ concentration, corresponding to the parameters like SST, wind, rainfall, and current speed that are required to study further dynamic processes and mechanisms, which influence the intensification of HABs and their role in coastal water for ecosystem changes. Distribution of Chl $a$ is primarily related to the wind driven at the coast and the currents that produced the region through the ocean color for spatiotemporal spreading of bloom. Similarly, the Chl $a$ and the SST distinctly separate at the coast of mixing and upwelling region at the adjacent water, which have been reflected from our result with the aid of SST, rainfall, wind speed, and direction. The same has been observed at distinct mixed zones near the coast at Tawain Street from AVHRR and SeaWiFS data result [57]. Any algal blooms or HABs appearance at the region could be identified and traced out easily from ocean color image as seen in Figure 5(a) and could be validated with near synchronous in situ data of cell densities. Considering the field observation in the present study, the Chl $a$ image of ocean factor and SST showed clear variation. This is due to the large freshwater influx with low temperature and salinities, which have been seen from in situ data of temperature and salinities. Similar conditions have been observed through the freshwater influx and HABs appearance at the Chinese coasts which made huge loss [58].

It has also been seen from a case of the coastal water of Norwegian water and the Omura bay of Japan linked to rain-runoff events due to the heavy precipitation, and nutrient addition induces the K. mikimotoi bloom in the region [59]. However, in the present study, the heavy rain fall was partially supported by the intensification of bloom that occurred during September. As the precipitation increases the 
Chl $a$ intensification decreases due to turbidity and freshens of the water under higher temperature variations. The similar environmental conditions occurred at the study site and the moderate salinities favored for the bloom (Figure 2(c)). It is also seen that the major river discharges or the riverine inputs have reflected the influential factor for triggering the K. mikimotoi and show the correlations between rainfall and cell densities followed. The present study indicates moderate rainfall triggered bloom intensification at the coast.

The neurotoxic shellfish poisoning (NSP) and azaspiracid shellfish poisoning (AZP), which are below detectable, formed due to the maximum bloom of K. mikimotoi assimilated by mussel Perna viridis at southern Kerala coast, did not show any toxicity to ecosystem and public health, proved by experiment of toxicity on mice. It was found the putrid smell that formed due to the deterioration of bloom, decaying fish, and sulphide gas released, resulted in the nausea and respiratory problem to the public health. Addition to this similar incidence has been reported in west coast during the same period of September 1997 by the consumption of mussel Perna indica, Karunasagar et al. [55], causing hospitalization and death. Another similar incidence has been observed due to the bloom affecting mussel Meretrix casta in Tamilnadu, and the causative species were unknown [56]. In the present study, the putrid smell from the crashing of the bloom decaying fish and $\mathrm{H}_{2} \mathrm{~S}$ emanating from the sea was wafted towards the coast. The wind also may carry some cell fragments of the phytoplankton from the crash of bloom leading to irritation of eyes and nasal membranes, coughing, and sneezing among the coastal population.

The spatiotemporal satellite remote sensing images are helpful in studying the movement of HABs, and its marine dynamic processes have advantages in detecting and tracing the algal blooms and could be well applicable to monitoring and forecasting on large scales. The Chl $a$ measure alone would not be sufficient for confirming any future bloom of K. mikimotoi without the satellite derived data of SST, rainfall, and wind pattern during the appearance of bloom. Similarly, the large fish mortality due to release of neurotoxic shellfish poisoning (NSP) and azaspiracid shellfish poisoning (AZP) by dinoflagellate could be predicted and prevented by remote sensing application. However, validation of bloom identification and cell counting through the microscope from ground truthing is always necessary. Presently, the data analysis has been suggested for the bloom in the region due to favorable condition of moderate rainfall, dilution of salinity, nutrient enrichment, low SST, and wind speed. Therefore, the frequency of occurrences of algal blooms in the region during study period was increased. Many are nontoxic in nature, indirectly affecting the fishery potential. The release of toxins from the present bloom was assessed by chemical and mouse bioassay method, showing negative results; nevertheless, crashing of bloom due to traced anoxic condition and abnormal mucus covering fish gills accentuate the fish kill. In this context, it appears necessary to strengthen our understanding of the links between the occurrence of blooms and the preceding environmental conditions in predicting the blooms and their impacts.

\section{Acknowledgments}

The authors are grateful to the Ministry of Earth Sciences, Government of India, for the financial support during the study period. The authors are grateful to Dr. C. S. P. Iyer, Former Head, Centre for Marine Analytical References and Standards (C-MARS), CSIR, Regional Research Laboratory, Thiruvananthapuram for his effective and constant encouragement and generous help, and Dr. G. Madhusoodhanan Pillai (Sredha Scientific Trust, Thiruvananthapuram) who rendered great service in the final stages of this work. Thanks are due to captain and crews of CRV Sagar Purvi during shipboard work.

\section{References}

[1] D. M. Anderson, S. B. Galloway, and J. D. Joseph, "Marine biotoxins and harmful algae: a national plan," Woods Hole Oceanographic Institution Technical Report, WHOI 93-02, Woods Hole Oceanographic Institution, Woods Hole, Mass, USA, 1993.

[2] T. A. Villareal, M. A. Brainard, and L. W. McEachron, "Gymnodinium breve in the western Gulf of Mexico: resident versus advected populations as a seed stock for blooms," in Proceedings of the 9th International Symposium on Harmful Algal Blooms, G. M. Hallegraeff, S. I. Blackburn, C. J. Bolch, and R. J. Lewis, Eds., pp. 153-156, Hobart, Tasmania, Australia, 2001.

[3] L. D. Mee, R. Cortes-Altamirano, and L. M. Garcia-de-la-Parra, "Di-nitrogen fixation in a eutrophic tropical bay," Estuarine, Coastal and Shelf Science, vol. 19, no. 4, pp. 477-483, 1984.

[4] A. Clément, M. Seguel, G. Arzul et al., "Widespread oubreak of haemolytic, ichthyotoxic Gymnodinium sp. in Southern Chile," in Proceedings of the 9th International Symposium on Harmful Algal Blooms, G. M. Hallegraeff, S. I. Blackburn, C. J. Bolch, and R. J. Lewis, Eds., pp. 66-69, Hobart, Tasmania, Australia, 2001.

[5] K. M. Lester, R. Merkt, C. A. Heil et al., "Evolution of a Gymnodinium breve (Gymnodiniales, Dinophyceae) red tide bloom on the west Florida shelf: relationship with organic nitrogen and phosphorus," in Proceedings of the 9th International Symposium on Harmful Algal Blooms, G. M. Hallegraeff, S. I. Blackburn, C. J. Bolch, and R. J. Lewis, Eds., pp. 61-64, Hobart, Tasmania, Australia, 2001.

[6] C. A. Heil, G. A. Vargo, D. Spence et al., "Nutrient stoichiometry of a Gymnodinium breve Davis (Gymnodiniales: Dinophyceae) bloom: what limits blooms in oligotrophic environments," in Proceedings of the 9th International Symposium on Harmful Algal Blooms, G. M. Hallegraeff, S. I. Blackburn, C. J. Bolch, and R. J. Lewis, Eds., pp. 165-168, Hobart, Tasmania, Australia, 2001.

[7] G. A. Vargo, C. A. Heil, D. N. Spence et al., "The hydrographic regime, nutrient requirements, and transport of a Gymnodinium breve DAVIS red tide on the West Florida shelf," in Proceedings of the 9th International Symposium on Harmful Algal Blooms, G. M. Hallegraeff, S. I. Blackburn, C. J. Bolch, and R. J. Lewis, Eds., pp. 157-160, Hobart, Tasmania, Australia, 2001.

[8] J. I. Carreto, H. R. Benavides, R. M. Negri, and P. D. Glorioso, "Toxic red-tide in the Argentine Sea. phytoplankton distribution and survival of the toxic dinoflagellate Gonyaulax excavata in a frontal area," Journal of Plankton Research, vol. 8, no. 1, pp. 15-28, 1986.

[9] G. C. Pitcher and A. J. Boyd, "Across-shelf and alongshore dinoflagellate distributions and the mechanisms of red tide formation within the southern Benguela upwelling system," in 
Proceedings of the 9th International Symposium on Harmful Algal Blooms, G. M. Hallegraeff, S. I. Blackburn, C. J. Bolch, and R. J. Lewis, Eds., pp. 243-2246, Hobart, Tasmania, Australia, 1996.

[10] G. C. Pitcher, A. J. Boyd, D. A. Horstman, and B. A. MitchellInnes, "Subsurface dinoflagellate populations, frontal blooms and the formation of red tide in the southern Benguela upwelling system," Marine Ecology Progress Series, vol. 172, pp. 253$264,1998$.

[11] M. A. Tyler and H. H. Seliger, "Annual subsurface transport of a red tide Dinoflagellate to its bloom area: water circulation patterns and organism distributions in the Chesapeake Bay," Limnology and Oceanography, vol. 23, pp. 227-246, 1978.

[12] M. A. Tyler and H. H. Seliger, "Selection for a red tide organism: physiological responses to the physical environment," Limnology and Oceanography, vol. 26, pp. 310-324, 1981.

[13] K. A. Steidinger, G. A. Vargo, and P. A. Tester, "Bloom dynamics and physiology of Gymnodinium breve with emphasis on the Gulf of Mexico," in Physiological Ecology of Harmful Algal Blooms, D. M. Anderson, A. D. Cembella, and G. M. Hallegraeff, Eds., pp. 133-153, Springer, Heidelberg, Germany, 1998.

[14] O. Lindahl, "Blooms of Gyrodinium aureolum along the Skagerrak coast-a result of the concentration off offshore populations," in Toxic Dinoflagellates, D. W. Anderson, A. W. White, and D. G. Baden, Eds., pp. 231-232, Elsevier Science, Amsterdam, The Netherlands, 1985.

[15] P. A. Tester, R. P. Stumpf, F. M. Vukovich, P. K. Fowler, and J. T. Turner, "An expatriate red tide bloom: transport, distribution, and persistence," Limnology and Oceanography, vol. 36, no. 5, pp. 1053-1061, 1991.

[16] I. S. Sordo, Y. Pazos, J. A. Triñanes et al., "The advection of a toxic bloom of Gymnodinium catenatum to the Galician Rias, detected from SST satellite images," in Proceedings of the 9th International Symposium on Harmful Algal Blooms, G. M. Hallegraeff, S. I. Blackburn, C. J. Bolch, and R. J. Lewis, Eds., pp. 149152, Hobart, Tasmania, Australia, 2000.

[17] K. Davidson, P. Miller, T. A. Wilding et al., "A large and prolonged bloom of Karenia mikimotoi in Scottish waters in 2006," Harmful Algae, vol. 8, no. 2, pp. 349-361, 2009.

[18] D. G. Baden, T. J. Mende, M. A. Poli et al., “Toxins from Florida’s red tide dinoflagellates, Ptychodiscus brevis," in Seafood Toxins, E. P. Regelis, Ed., pp. 359-367, American Chemical Society, Washington, DC, USA, 1984.

[19] H. Yang and R. H. Weisberg, "Response of the West Florida shelf circulation to climatological wind stress forcing," Journal of Geophysical Research C, vol. 104, no. 3, pp. 5301-5320, 1999.

[20] F. G. Camacho, J. G. Rodríguez, A. S. Mirón et al., "Biotechnological significance of toxic marine dinoflagellates," Biotechnology Advances, vol. 25, no. 2, pp. 176-194, 2007.

[21] P. M. Glibert, J. H. Landsberg, J. J. Evans et al., "A fish kill of massive proportion in Kuwait Bay, Arabian Gulf, 2001: the roles of bacterial disease, harmful algae, and eutrophication," Harmful Algae, vol. 1, no. 2, pp. 215-231, 2002.

[22] B. W. Halstead and E. J. Schantz, "Paralytic shellfish poisoning," World Health Organization Offset Publication, no. 79, pp. 1-60, 1984.

[23] M. D. Dickman, "Hong Kong's worst red tide induced fish kill (March-April 1998)," in Proceedings of the 9th International Symposium on Harmful Algal Blooms, G. M. Hallegraeff, S. I. Blackburn, C. J. Bolch, and R. J. Lewis, Eds., pp. 58-61, Hobart, Tasmania, Australia, 2001.
[24] K. Grasshoff, M. Ehrhardt, and K. Kremling, Methods of Sea Water Analysis, Verlag Chemie, Weinheim, Germany, 3rd edition, 1999.

[25] UNESCO, "Protocols for the Joint Global Ocean Flux Study (JGOFS)," Core Measurements, IOC Manual and Guides 29, 1994.

[26] American Public Health Association (APHA), Standard Methods for the Estimation Water and Waste Water, American Public Health Association, Washington, DC, USA, 18th edition, 1995.

[27] T. R. Parsons, Y. Maita, and C. M. Lalli, Eds., A Manual of Chemical and Biological Methods for Sea Water Analysis, Pergamon Press, New York, NY, USA, 1984.

[28] H. Utermohl, "Zur Vervollkommung derquantitativen phytoplankton-methodik," Mitteleuropa Internationale Verein Limnologie, vol. 9, pp. 1-38, 1958.

[29] E. W. Truby, "Preparation of single-celled marine dinoflagellates for electron microscopy," Microscopy Research and Technique, vol. 36, pp. 337-340, 1997.

[30] A. Sournia, Phytoplankton Manual, UNESCO, Paris, France, 1978.

[31] R. Santhanam, R. M. Ramanadhan, and K. G. V. Jagatheesan, Phytoplankton of the Indian Seas, Daya Publishing House, New Delhi, India, 1987.

[32] AOAC, "Paralytic shellfish poison," in Official Methods of Analysis, K. Helrich, Ed., pp. 59-61, Association of Official Analytical Chemists, Arlington, Tex, USA, 2000.

[33] N. Daugbjerg, G. Hansen, J. Larsen, and O. Moestrup, "Phylogeny of some of the major genera of dinoflagellates based on ultrastructure and partial LSU rDNA sequence data, including the erection of three new genera of unarmoured dinoflagellates," Phycologia, vol. 39, no. 4, pp. 302-317, 2000.

[34] V. P. Devassy, P. M. A. Bhattathiri, and S. Z. Qasim, "Trichodesmium phenomenon," Indian Journal of Marine Science, vol. 7, pp. 168-186, 1978.

[35] G. S. Sharma, "Upwelling off the Southwest coast of India," Indian Journal of Marine Science, vol. 7, pp. 209-218, 1978.

[36] P. Gentien, "Bloom dynamics and ecophysiology of the Gymnodinium mikimotoi species complex," in Physiological Ecology of Harmful Algal Blooms, D. M. Anderson, A. D. Cembella, and G. M. Hallegraeff, Eds., pp. 155-173, Springer, Heidelberg, Germany, 1998.

[37] M. W. Lomas, P. M. Glibert, G. M. Berg, and M. Burford, "Characterization of nitrogen uptake by natural populations of Aureococcus anophagefferens (Chrysophyceae) as a function of incubation duration, substrate concentration, light, and temperature," Journal of Phycology, vol. 32, no. 6, pp. 907-916, 1996.

[38] R. M. Kudela and W. P. Cochlan, "Nitrogen and carbon uptake kinetics and the influence of irradiance for a red tide bloom off Southern California," Aquatic Microbial Ecology, vol. 21, no. 1, pp. 31-47, 2000.

[39] P. M. Glibert, R. Magnien, M. W. Lomas et al., "Harmful algal blooms in the Chesapeake and coastal bays of Maryland, USA: comparison of 1997, 1998, and 1999 events," Estuaries, vol. 24, no. 6 A, pp. 875-883, 2001.

[40] R. Margalef, "Life-forms of phytoplankton as survival alternatives in an unstable environment," Oceanologica Acta, vol. 1, pp. 493-509, 1978.

[41] P. M. Holligan, "Dinoflagellate blooms associated with tidal fronts around the British Isles," in Toxic Dinoflagellate Blooms, D. L. Taylor, H. H. Seliger, and C. M. Lewis, Eds., pp. 89-94, Elsevier, Amsterdam, The Netherlands, 1979. 
[42] K. J. Jones, R. J. Gowen, and P. Tett, "Water column structure and summer phytoplankton distribution in the Sound of Jura, Scotland," Journal of Experimental Marine Biology and Ecology, vol. 78, no. 3, pp. 269-289, 1984.

[43] C. E. Smith and R. G. Piper, "Lesions associated with chronic exposure to ammonia," in The Pathology of Fishes, W. E. Ribelin and G. Migaki, Eds., pp. 497-514, University of Wisconsin Press, Madison, Wis, USA, 1975.

[44] B. C. Nguyen, S. Belviso, N. Mihalopoulos, J. Gostan, and P. Nival, "Dimethyl sulfide production during natural phytoplanktonic blooms," Marine Chemistry, vol. 24, no. 2, pp. 133141, 1988.

[45] Y. Hishida, A. Ishimatsu, and T. Oda, "Mucus blockade of lamellar water channels in yellowtail exposed to Chattonella marina," Fisheries Science, vol. 63, no. 2, pp. 315-316, 1997.

[46] A. La Barbera Sanchez, S. Hall, and E. F. Reyes, "Alexandrium sp. Gymnodinium cateantum and PSP in Venezuela," in Toxic Dinoflagellates Blooms in the Sea, T. J. Smaida and Y. Shimisu, Eds., pp. 281-282, Elsevier, Amsterdam, The Netherlands, 1993.

[47] R. W. Holmes, P. M. Williams, and R. W. Eppley, "Red water in La Jolla Bay, 1964-1966," Limnology and Oceanography, vol. 12, pp. 503-512, 1967.

[48] J. A. Hellebust, "Excretion of some organic compounds by marine phytoplankton," Limnology and Oceanography, vol. 10, pp. 192-206, 1965.

[49] T. J. Smayda, "Turbulence, watermass stratification and harmful algal blooms: an alternative view and frontal zones as 'pelagic seed banks"' Harmful Algae, vol. 1, no. 1, pp. 95-112, 2002.

[50] G. Gunther, R. H. Willams, C. C. Davis, and F. G. W. Smith, "Catastrophic mass mortality of marine animals and coincident phytoplankton bloom on the West coast of Florida, November, 1946 to August, 1947," Ecological Monographs, vol. 18, no. 3, pp. 309-324, 1948.

[51] Y. Yamasaki, D. I. Kim, Y. Matsuyama, T. Oda, and T. Honjo, "Production of superoxide anion and hydrogen peroxide by the red tide dinoflagellate Karenia mikimotoi," Journal of Bioscience and Bioengineering, vol. 97, no. 3, pp. 212-215, 2004.

[52] T. Oda, T. Akaike, K. Sato et al., "Hydroxyl radical generation by red tide algae," Archives of Biochemistry and Biophysics, vol. 294, no. 1, pp. 38-43, 1992.

[53] D. M. Miller, G. R. Buettner, and S. D. Aust, "Transition metals as catalysts of "autoxidation" reactions," Free Radical Biology and Medicine, vol. 8, no. 1, pp. 95-108, 1990.

[54] D. Kim, A. Nakamura, T. Okamoto et al., "Mechanism of superoxide anion generation in the toxic red tide phytoplankton Chattonella marina: possible involvement of NAD(P)H oxidase," Biochimica et Biophysica Acta, vol. 1524, no. 2-3, pp. 220227, 2000.

[55] I. Karunasagar, B. Joseph, K. K. Philipose et al., "Another outbreak of PSP in India," Harmful Algae News, vol. 17, article 1, 1998.

[56] S. R. Bhat and S. G. P. Matondkar, "Algal blooms in the seas around India-networking for research and outreach," Current Science, vol. 87, no. 8, pp. 1079-1083, 2004.

[57] D. L. Tang, H. Kawamura, and L. Guan, "Long-time observation of annual variation of Taiwan strait upwelling in summer season," Advances in Space Research, vol. 33, no. 3, pp. 307-312, 2004.

[58] D. Tang, D. R. Kester, I. H. Ni, Y. Qi, and H. Kawamura, "In situ and satellite observations of a harmful algal bloom and water condition at the Pearl River estuary in late autumn 1998," Harmful Algae, vol. 2, no. 2, pp. 89-99, 2003.
[59] T. J. Smayda, "Eutrophication and phytoplankton," in Integrated Approaches to Drainage Basin Nutrient Inputs and Coastal Eutrophication, P. Wassmann and K. Olli, Eds., pp. 89-98, Electronic-Book, 2004, http://kodu.ut.ee/ olli/eutr/. 

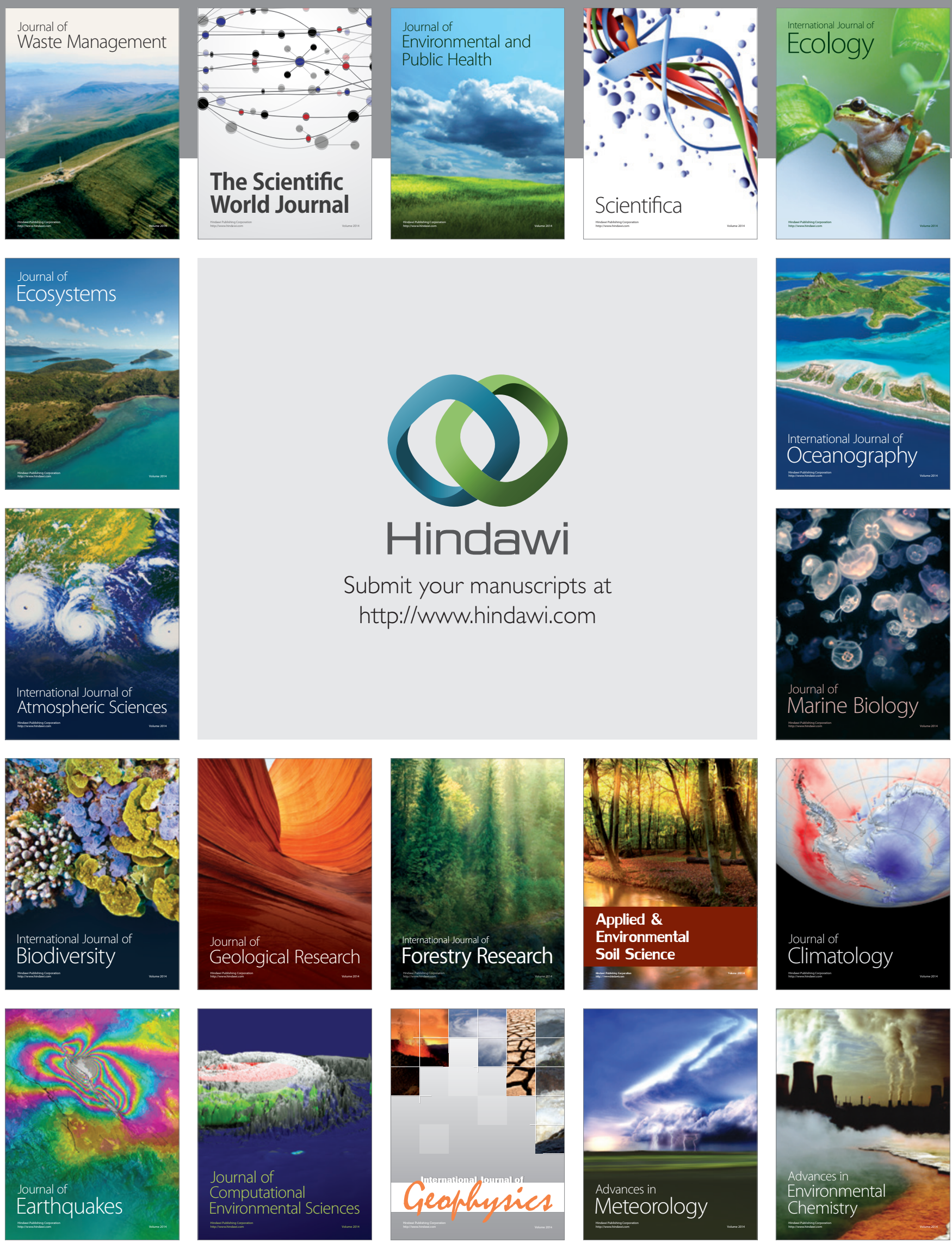